\title{
The Impact of Large Variations of the Earth's Obliquity on the Climate
}

\author{
By B. G. Hunt \\ Australian Numerical Meteorology Research Centre \\ Melbourne, Australia 3001 \\ (Manuscript received 12 October 1981, in revised form 1 November 1981)
}

\begin{abstract}
A hemispheric general circulation model set up for annual mean conditions has been used to investigate the consequences of varying the obliquity from $23.5^{\circ}$ to $0^{\circ}$ and $65^{\circ}$. Such obliquity values have been claimed to have occurred in past eras. The $0^{\circ}$ obliquity climate is more vigorous than the existing climate, but also drier and colder at the surface at high latitudes. However, overall a slight warming of the troposphere occurred in the model. Two experiments were performed for $65^{\circ}$ obliquity, both had low albedoes at high latitudes, while one had glacial albedoes at low latitudes. For annual mean conditions there was virtually no tropospheric latitudinal temperature gradient in the first experiment, and consequently greatly reduced mean zonal winds and baroclinic activity. The second experiment had minimum surface temperatures in the tropics, but still sufficiently high to prevent glacial conditions prevailing, and consequently a tropical easterly jet maintained by a "reversed Hadley cell". Other aspects such as the simulated hydrology, energy exchanges, etc. provide considerable enlightenment concerning climatic conditions at such extreme obliquity. It is concluded that the Earth's habitable zone would be reduced for both $0^{\circ}$ and $65^{\circ}$ obliquity. These experiments illustrate the considerable unexploited potential of general circulation models in evaluating hypothetical climatic states which have veen proposed at various times.
\end{abstract}

\section{Introduction}

The obliquity, or angle of tilt of a planet's axis from the vertical, is generally surmised to play an important role in that planet's climate. Thus the potential climatic effects on the Earth of small obliquity variations, $\pm 1.5^{\circ}$ from the current value of $23.5^{\circ}$, associated with the Milankovitch theory of glaciation have recently been discussed by Kukla et al. (1981). However, over the last 100 years or so there have been numerous claims in the literature that very large obliquity variations have occurred on Earth during past ages. For example, based on palaeobotanical evidence Wolfe (1978) has suggested that about 45 million years ago the Earth's obliquity was only $5^{\circ}$. At the other extreme Williams (1975) on geological grounds has hypothesized that the obliquity was greater than $54^{\circ}$ during the late Precambrian (about 800 million years ago) in order to account for the existence of low latitude glaciation.
Since comprehensive reconstructions of palaeoclimates are difficult to obtain from experimental data it is important that alternative tests of the above obliquity variations should be performed. General circulation models of the atmosphere provide a unique tool for such assessments, as they are able to synthesize the climate in a dynamically consistent manner for selected variations in boundary conditions. To date most general circulation models have been used very conservatively as regards this potential, but it is to be hoped that a more imaginative exploitation of their capabilities will occur in the future. The present study arose in response to comments by Williams (1980) on a prior experiment, Hunt $(1979,1980)$ involving large variations of the Earth's rotation rate; the current experiment is concerned with comparing the climatic states of the Earth for obliquity values of $0^{\circ}, 23.5^{\circ}$ and $65^{\circ}$ as simulated with a general circulation model. Only the basic climatic response will be con- 
sidered here, the palaeoclimatic implications will be discussed elsewhere.

\section{Model description}

The general circulation model used has been described in some detail previously by Hunt (1976). Briefly it is a northern hemispheric gridpoint model based on a stereographic projection with 20 points between the pole and the equator. It has 18 vertical levels distributed between the surface and $37.5 \mathrm{~km}$. The model is non-diurnal, annual mean and devoid of topography, but includes the hydrologic cycle and a comprehensive radiation scheme employing zonal mean climatological clouds, water vapour, ozone, carbon dioxide and surface albedoes. The surface temperature is calculated using a 'swamp' condition everywhere, implying zero heat capacity but an infinite source of water.

The $23.5^{\circ}$ obliquity experiment is the control or standard simulation, which gives a fair representation of the annual mean atmosphere as discussed in detail in Hunt (1976). The $0^{\circ}$ obliquity experiment (OBL1) differed from the control only as regards the mean solar zenith angle used in the radiation calculations, which was redefined with values appropriate to this obliquity. Two experiments were performed for $65^{\circ}$ obliquity. In addition to having redefined mean solar zenith angles, experiment OBL2 had its high polar albedoes reset to 0.1 in the expectation that surface temperatures too high to maintain snow or ice would exist at these latitudes for $65^{\circ}$ obliquity. The second experiment, OBL3, had the same modifications as OBL2 but with the low latitude albedoes reset to annual mean ice and snow values, to provide a fair check of the tropical glaciation theory for such an obliquity. The latitudinal variation of the zonal mean albedoes used is given in Fig. 1.

In addition to these experiments a "noise" run was also made to provide a quantitative measure of the natural variability of the basic model. This consisted of inserting, at the $500 \mathrm{mb}$ level, random temperature perturbations in the range $\pm 1^{\circ} \mathrm{K}$ into an initial model field taken from the control, and running the model out to equilibrium.

The use of a hemispheric, annual mean model in these experiments requires some comment. The OBL1 case is probably reasonably represented by the model, as no seasonal or interhemispheric variations would occur for this situation. As regards OBL2 and OBL3 the

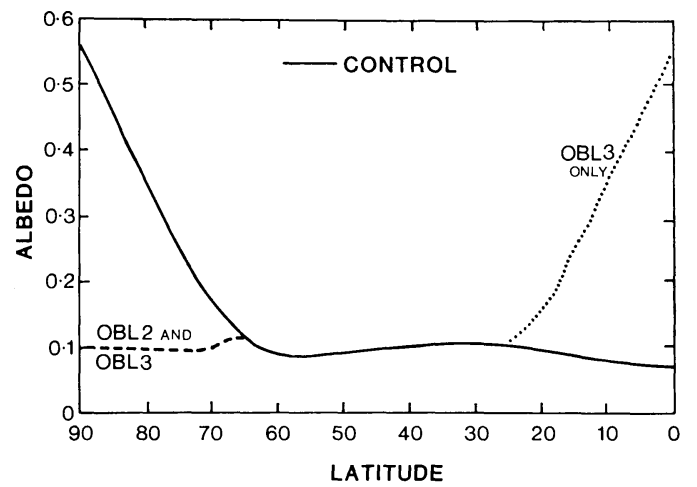

Fig. 1 Zonal mean surface albedo for the various experiments. CONTROL is the standard, unmodified model. OBL1 is the $0^{\circ}$ obliquity experiment which had the same surface albedo as the CONTROL. OBL2 and OBL3 are the $65^{\circ}$ obliquity experiments, both of which had reduced surface albedoes at high latitudes. In addition OBL3 had high surface albedo at low latitudes to allow for the possibility of tropical glaciation.

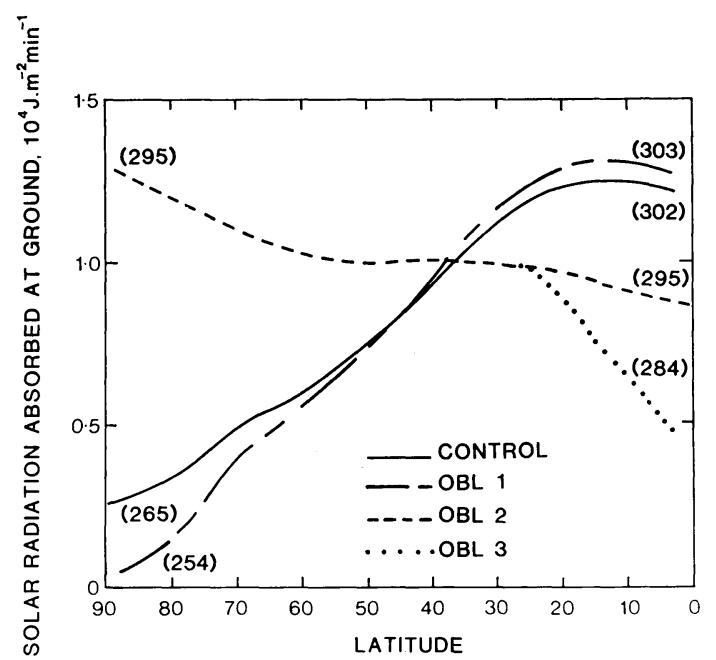

Fig. 2 Solar radiation absorbed at the surface for the control, OBL1, OBL2 and OBL3 cases for annual mean conditions. The bracketed numbers give the surface temperatures for the various experiments at the indicated latitudes.

annual mean results provide no indication of the extreme seasonality and strong interhemispheric interactions associated with an obliquity of $65^{\circ}$. Of more importance is whether the model represents the "true" annual mean of a seasonally varying global model. Judged simply by the solar flux absorbed at the surface in the various experiments, Fig. 2, it appears that the model may actually perform rather better 
than expected. For example the control curve in Fig. 2 essentially implies the observed annual mean latitudinal surface temperature distribution, hence it is reasonable to assume that the curves for OBL2 and OBL3 also imply the corresponding annual mean latitudinal surface temperature distributions for these runs. This is certainly the case for OBL1 where misinterpretation of the results is unlikely. It is important to note that these solar absorptions are largely determined by geometry, with some modification due to albedo. Hence for OBL2 a fairly isothermal, annual mean surface temperature might be predicted, while OBL3 would only differ by predicting lower tropical temperatures. These predictions are actually realised by the model integrations as demonstrated below. Since the dynamical fields in the model are largely determined by the thermal distribution it seems that the overall simulation may not be too unrealistic of the "true" annual mean situation.
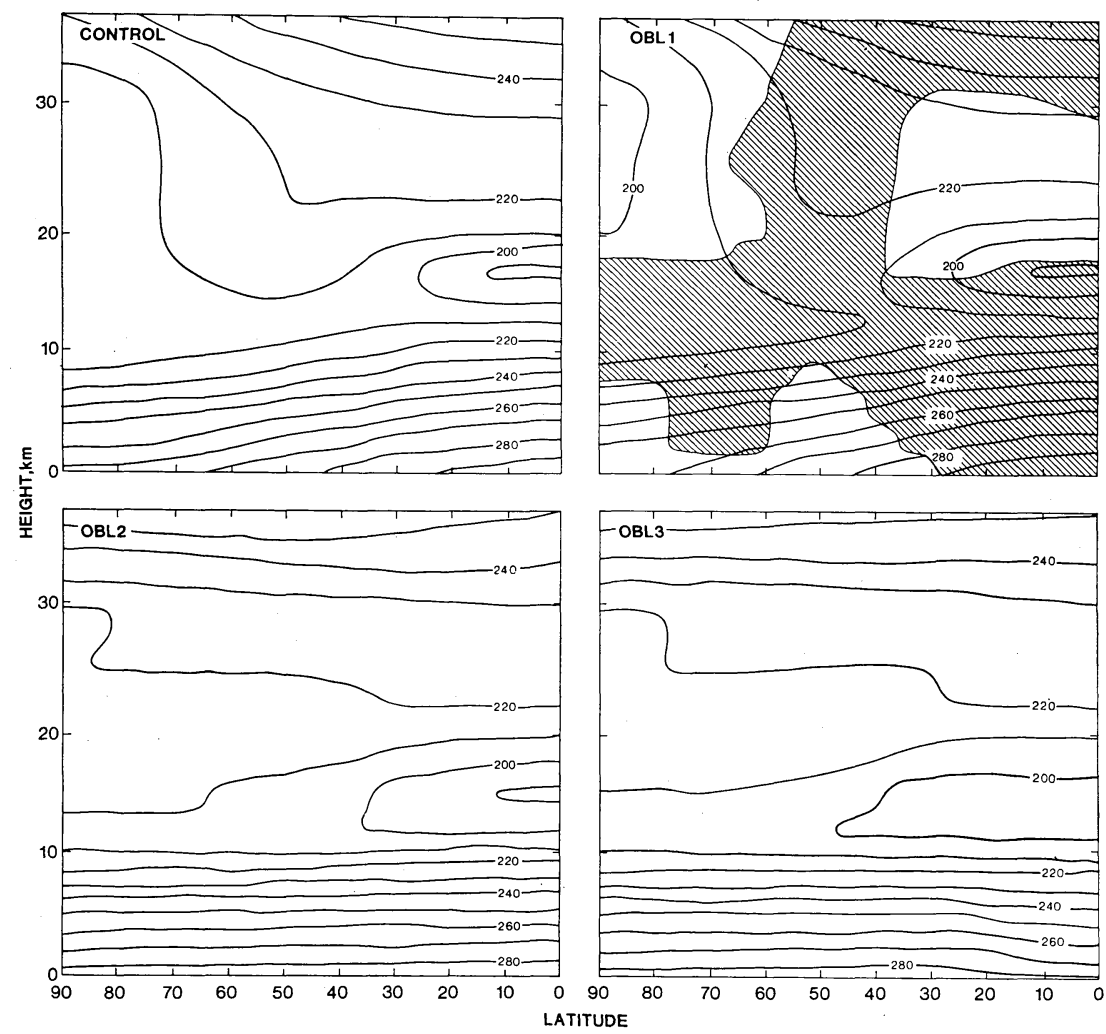

Fig. 3 Zonal mean temperature distributions. The various experiments are identified in the top left hand corner of the individual panels. The hatched area of the OBL1 panel indicates where it was warmer than the control (units: ${ }^{\circ} \mathrm{K}$ ). 


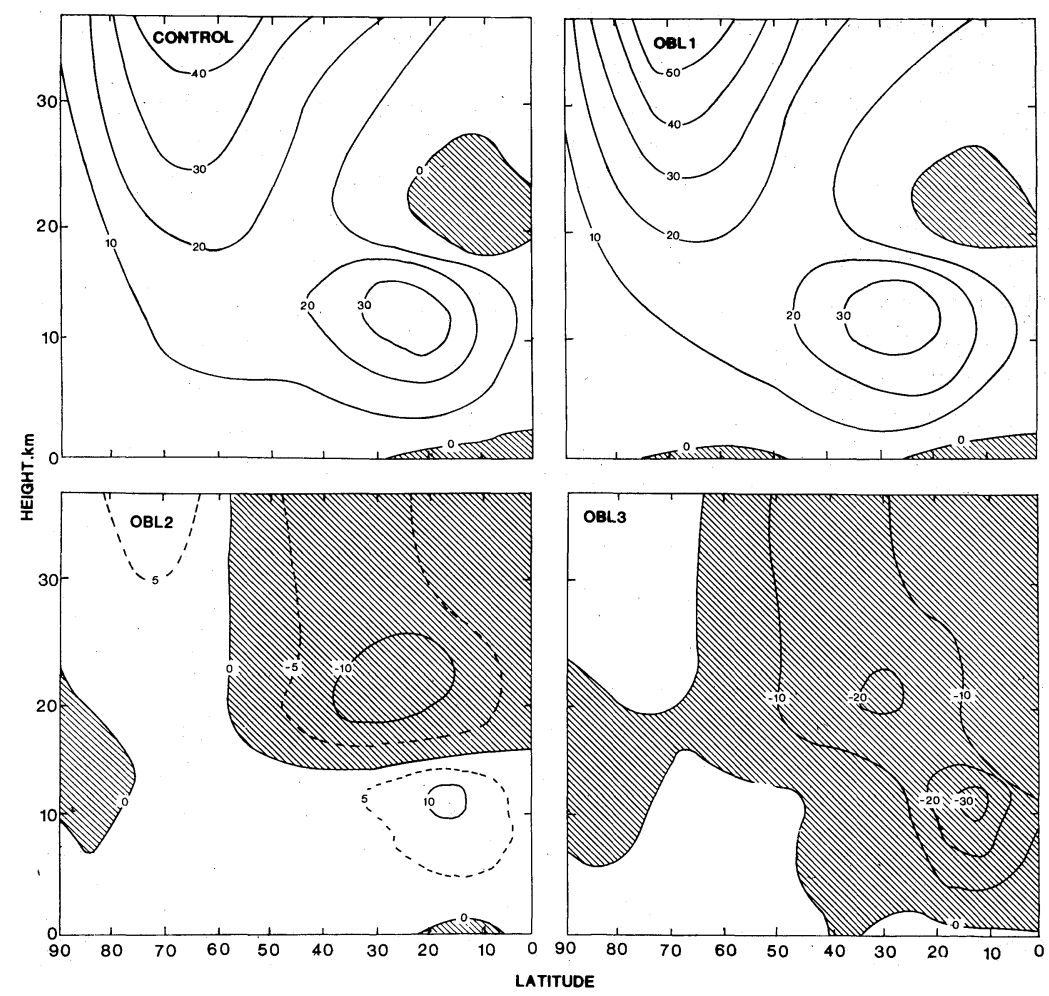

Fig. 4 Mean zonal winds distributions. The various experiments are identified in the top left hand corner of the individual panels. Hatched areas are regions with east winds (units: $\mathrm{m} \mathrm{s}^{-1}$ ).

OBL1 were in fact about $10^{\circ} \mathrm{K}$ cooler than the control, while being around $1^{\circ} \mathrm{K}$ warmer in the tropics. However, over most of the troposphere OBL1 was warmer than the control, as indicated in Fig. 3, while over most of the stratosphere it was colder both at high and low latitudes. Thus a simple response to the obliquity change was not obtained.

As expected from the thermal wind equation there was a slight intensification of both jet cores of the mean zonal wind in OBL1 compared to the control, see Fig. 4, while in the mid-latitude middle troposphere the winds were slightly stronger in the control. The mean meridional streamfunction in Fig. 5 shows a marginal strengthening of the Hadley and Ferrel cells in OBL1, but the most noticeable difference was the weaker polar (3rd) cell in the control run. The latitudinal precipitation rate was almost identical in the two experiments, while the evaporation rate was slightly higher at low latitudes and reduced polewards of $45^{\circ}$ in OBL1. The latter variations essentially reflect the surface temperature differences, although their crossover point was at $33^{\circ}$ latitude.

In summary these results imply that the climatic zonations on the Earth would not vary greatly for $0^{\circ}$ obliquity, but that the climate at very high latitudes would be considerably harsher in view of the reduced temperatures.

Compared to the control the various energy terms in OBL1 were about $10 \%$ larger, a difference significant with respect to a noise run. The eddy available potential energy showed the greatest enhancement. The higher energy in OBL1 can be attributed to the increased equator to pole temperature gradient in the troposphere, which occurred despite the fact that overall the troposphere in OBL1 was warmer than in the control. Thus higher baroclinicity was to be expected in OBL1, and was evident from a $10 \%$ increase in the rate of conversion between the eddy available potential energy and the eddy kinetic energy. The resulting enhanced wave activity in OBL1 can be observed in Fig. 6, being particularly noticeable in mid-latitudes. Synoptic charts of other atmospheric variables at various levels confirmed this general conclusion and, in particular, 


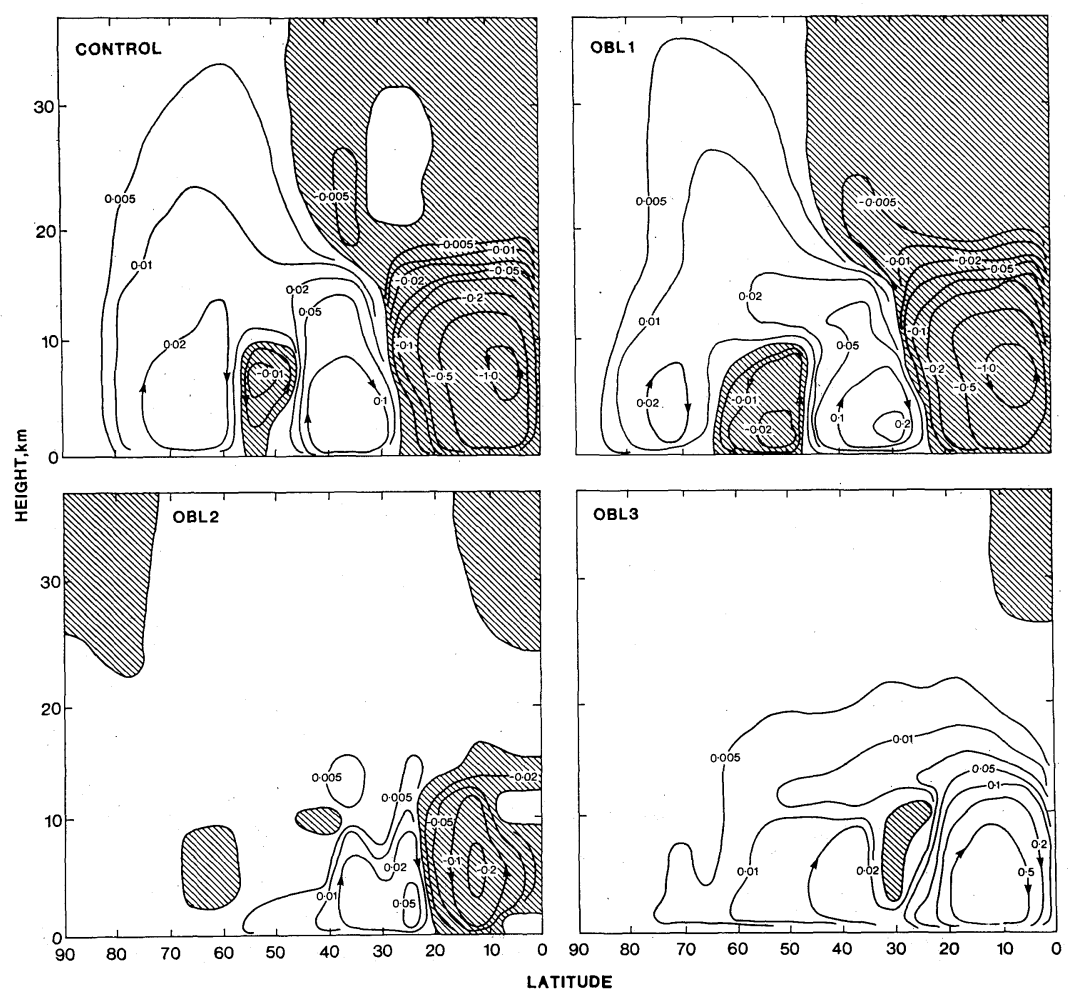

Fig. 5 Mean meridional streamfunctions. The various experiments are identified in the top left hand corner of the individual panels (units: $10^{11}$ $\mathrm{kg} \mathrm{s}^{-1}$ ).

indicated that greater storminess would occur in mid-latitudes for an obliquity of $0^{\circ}$. Judging solely by the relative humidity the cloudiness in OBL1 would not differ much from the control, if the model forecast clouds, except perhaps for a very slight reduction in the subtropics.

The principal factor in determining the latitudinal temperature change between OBL1 and the control was the polewards total (sensible plus latent) heat flux owing to large scale eddies, see Fig. 7. The noticeable increase in this flux for OBL1 polewards of $30^{\circ}$ latitude was a reflection of the change in baroclinic activity. The convergence of this heat flux in middle and high latitudes readily accounted for the general warming of the middle and upper troposphere in these regions apparent in Fig. 3. The resulting higher equilibrium temperatures were primarily balanced by a larger net radiative cooling. The colder polar temperatures in the near surface layers in OBL1 are thought to be caused by the lower solar input to the surface necessitating an increased downwards sensible heat flux into the surface, thereby extracting heat from the atmos- phere. Even then this heat flux was unable to prevent a surface cooling of about $10^{\circ} \mathrm{K}$ at these latitudes. Overall the hemispheric mean atmospheric temperature for OBL1 was $0.4^{\circ} \mathrm{K}$ warmer than the control, while the corresponding surface temperature was $1.1^{\circ} \mathrm{K}$ colder.

\section{4. $65^{\circ}$ obliquity experiments}

These experiments, OBL2 and OBL3, showed marked variations from the control. The annual mean simulations presented here should provide a modest representation of the mean seasonal cycle obtained by integrating a seasonally varying model, for reasons discussed in Section 2. In any case the simulations are intrinsically interesting, they may be appropriate to conditions around the autumnal equinox.

Returning to Fig. 3 it is clear that a most surprising situation existed as regards the temperature distributions for OBL2 and OBL3. The surface and troposphere of OBL2 were virtually isothermal as a function of latitude, while in the stratosphere the latitudinal temperature gradients were much reduced compared to the control, 

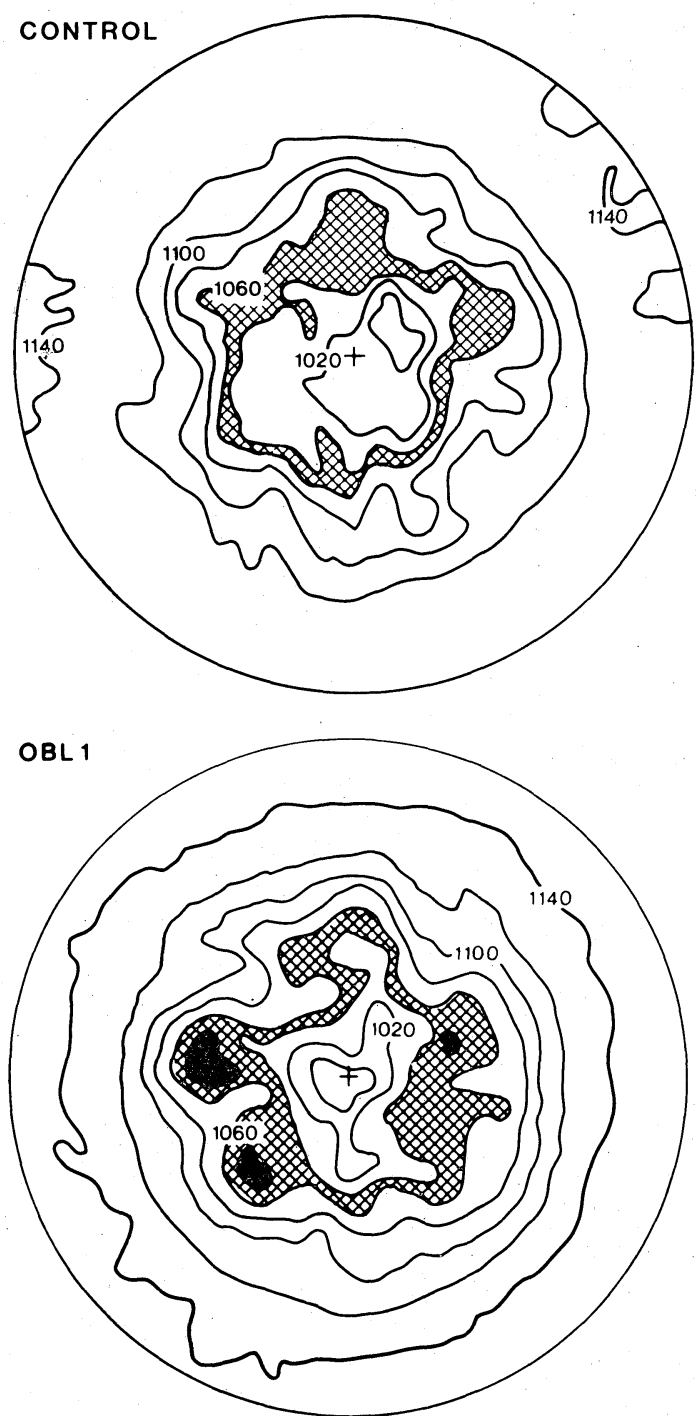

Fig. 6 Representative instantaneous synoptic distributions of geopotential height for model level $11,10.9 \mathrm{~km}$, are shown in the upper and lower halves of the figure for the control and OBL1 respectively for the same time (units: dam).

with the gradient being reversed in the top level. In OBL3 the low latitude temperatures were less than in OBL2, by about $10^{\circ} \mathrm{K}$ at the equator, in conformity with the higher surface albedoes. Even then the equatorial surface temperature of about $284^{\circ} \mathrm{K}$ was well above freezing point. Polewards of $25^{\circ}$ latitude OBL3 had very similar temperatures to OBL2, and again almost no latitudinal temperature gradient. The tropospheric temperatures in Fig. 3 are basically implied by the solar input variations in Fig. 2.

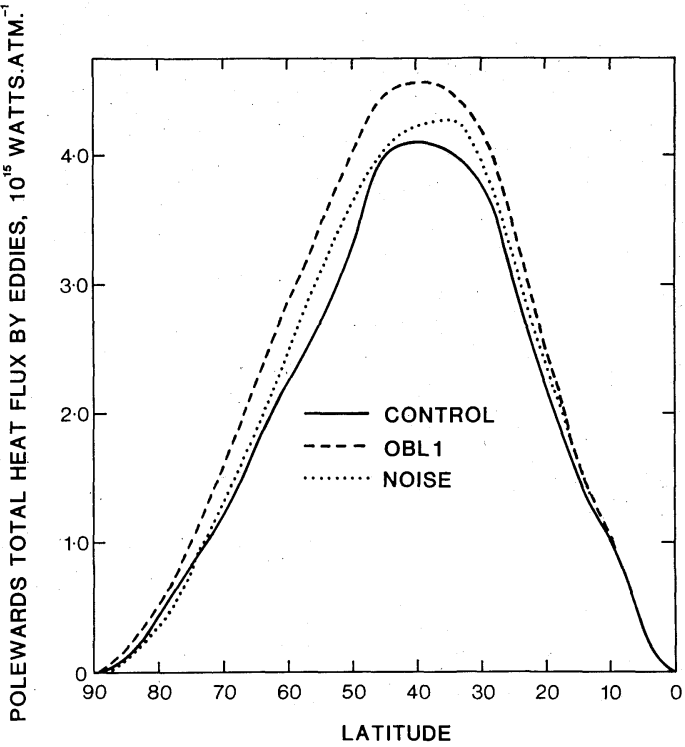

Fig. 7 Vertically integrated polewards fluxes of total heat owing to large scale eddies.

The associated mean zonal wind distributions in Fig. 4 essentially follow from the temperature variations. For OBL2 the westerly jet cores were very weak, although west winds still prevailed over most of the troposphere. The low latitude stratospheric easterlies on the other hand strengthened and extended very considerably. The situation for OBL3 was even more extreme, because the reversal of the low latitude temperature gradient resulted in the domination by east winds. The westerly jet cores were entirely removed, with the strongest winds now being easterlies located in the tropics where the maximum wind intensity attained was $34 \mathrm{~m} \mathrm{~s}^{-1}$. The conventional tropical surface easterlies were replaced by westerlies as the "Hadley cell" reversed its direction.

This situation is illustrated in Fig. 5 where the mean meridional streamfunctions are compared. For OBL2 essentially only a remnant of the control streamfunction persisted, with intensities reduced to $1 / 5$ th. However, it should be noted that owing to the numerical techniques used to produce the streamfunction, the Hadley cell in OBL2 appears somewhat more sharply defined at the equator than the actual mean meridional wind distribution there would suggest. Given the uniformity of the tropospheric temperature distirbution for OBL2 it is perhaps surprising that a Hadley cell existed at all. In the case of OBL3 both the troposphere and stratosphere were dominated by a large reverse cell emanating from the 
tropics. The production of such a cell in OBL3 is reasonable in view of the tropical energy imbalance relative to higher latitudes, and this situation should be contrasted with that in the control run which results in the Hadley cell. The maximum intensity of the indirect cell in OBL3 was about $80 \%$ of the Hadley cell in the control. An extremely weak direct cell existed near $30^{\circ}$ latitude but appears to be of little influence. The isothermal nature of the extratropical atmosphere in OBL3 presumably deterred the production of a series of independent cell such as occurred in the control. The differences between OBL2 and OBL3 in Fig. 5 were entirely attributable to the higher tropical surface albedoes in OBL3, and provide a very powerful illustration of the potential for surface albedo variations to influence the climate.

Before discussing how the climatic states of OBL2 and OBL3 were maintained it is advantageous to consider the synoptic distributions. For example the surface pressure charts for OBL3, and particularly OBL2, were almost featureless, as were the surface temperature distributions. In the troposphere there were more signs of wave activity and Fig. 8 is a representative example of the model behaviour. Compared to the control OBL2 had a remarkably uniform zonal wind distribution, while its meridional wind was not only weaker but apparently of higher wave number and different character. OBL3 was far more active than OBL2 with meridional velocities much closer to those of the control in character, if not in intensity. The strong easterly jet associated with the reversed temperature gradient at low latitudes in OBL3 is very clearly shown in Fig. 8. It had a more coherent structure than the westerly jet core in the control because of the weak, secondary role of the large scale eddies in OBL3 (and OBL2). The angular momentum for the tropical easterlies in OBL3 was supplied by the mean meridional motions as might be deduced from Fig. 5. Excessive east winds were prevented by large scale eddies converging westerly momentum into the region of the tropical jet core. The overall angular momentum balance in OBL2 was similar to that of the control, but of much reduced intensity.

Considerable insight can be obtained into how the temperature distributions for OBL2 and OBL3 evolved from examination of Fig. 2. At low latitudes the surface temperatures for the experiments were ordered in relationship to the solar radiation absorbed at the surface, and were
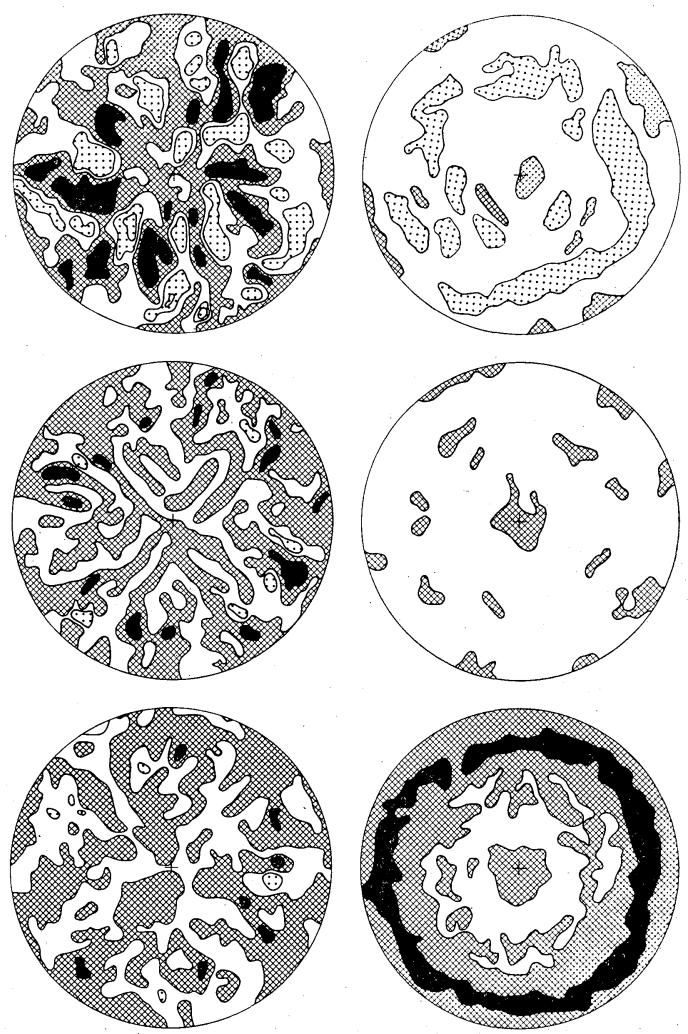

Fig. 8 Instantaneous synoptic distributions of meridional velocity (left hand side) and zonal velocity (right hand side) for the control, OBL2 and OBL3 are shown in the top, middle and bottom of the figure respectively. The colour coding for the meridional velocity is: black, south winds above $10 \mathrm{~m} \mathrm{~s}^{-1}$; double hatching, south winds $0-10 \mathrm{~m} \mathrm{~s}^{-1}$; clear, north winds 0 $10 \mathrm{~m} \mathrm{~s}^{-1}$; stippled, north winds above $10 \mathrm{~m} \mathrm{~s}^{-1}$. The colour coding for the zonal velocity is: black, east winds above $30 \mathrm{~m} \mathrm{~s}^{-1}$; double hatching, east winds $0-30 \mathrm{~m} \mathrm{~s}^{-1}$; clear, west winds, $0-30 \mathrm{~m} \mathrm{~s}^{-1}$; stippled west winds above $30 \mathrm{~m} \mathrm{~s}^{-1}$. All results are for a height of $10.9 \mathrm{~km}$.

much as expected. At polar latitudes Fig. 2 suggests that somewhat higher surface temperatures than obtained might have been expected in both OBL2 and OBL3. Such temperatures did not eventuate because convective activity was very much stronger in the polar region than in the control, owing to the higher temperatures, and the incoming solar energy was efficiently distributed throughout the depth of the troposphere. Fig. 2 also indicates that essentially isothermal surface temperatures might be expected from $60^{\circ}$ to the equator in OBL2 and from $60^{\circ}$ to $25^{\circ}$ in OBL3, as shown in Fig. 3. 


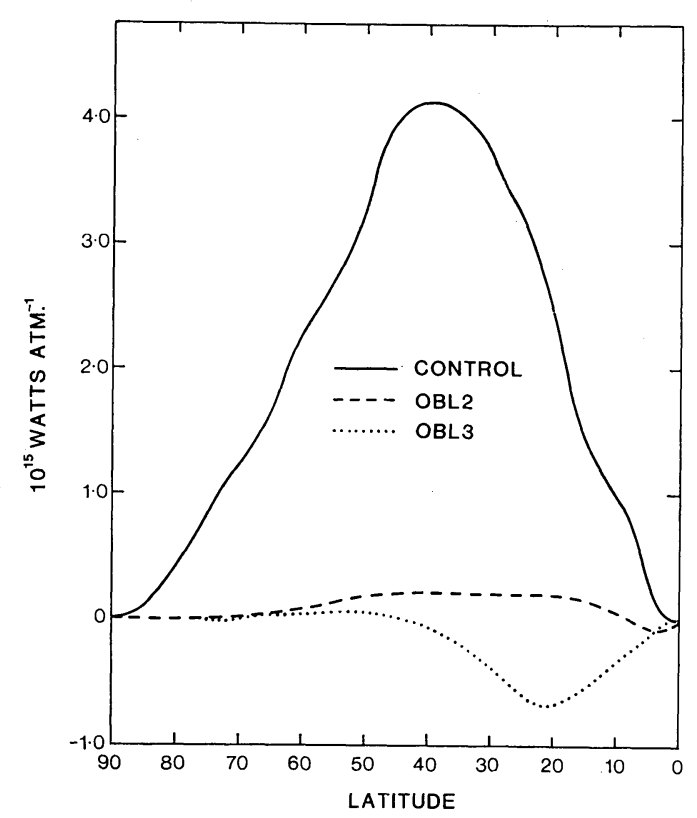

Fig. 9 Vertically integrated polewards fluxes of total heat owing to large scale eddies.

Implicit in the above discussion is the supposition that meridional transports of energy do not play as large a role as they do in the control. This is readily confirmed as regards the large scale eddy fluxes of heat, see Fig. 9, which should also be contrasted with Fig. 7. This minor heat transport, particularly for OBL2, was to be expected given the highly reduced baroclinic instability implicit in the latitudinal temperature gradients, and the associated quiescent nature of the synoptic distributions compared to the control, see Fig. 8. In fact the latitude height distribution of the polewards flux of sensible heat owing to large scale eddies was weak and poorly organised for OBL2, while for OBL3 the dominant features was an equatorwards flux concentrated in the lowest $2 \mathrm{~km}$ of the subtropical troposphere. A somewhat similar situation prevailed for the latent heat flux. Interestingly the heat flux distribution in Fig. 9 for OBL3 may be reasonably representative of that existing for summer conditions at high obliquity. For this situation higher temperatures would be expected in the polar region than the tropics, as obtained in OBL3 for different reasons, with a consequent equatorwards directed large scale eddy heat flux.

For most latitudes the heat balance in the tropospheres of OBL2 and OBL3 essentially consited of mutual compensation between the net

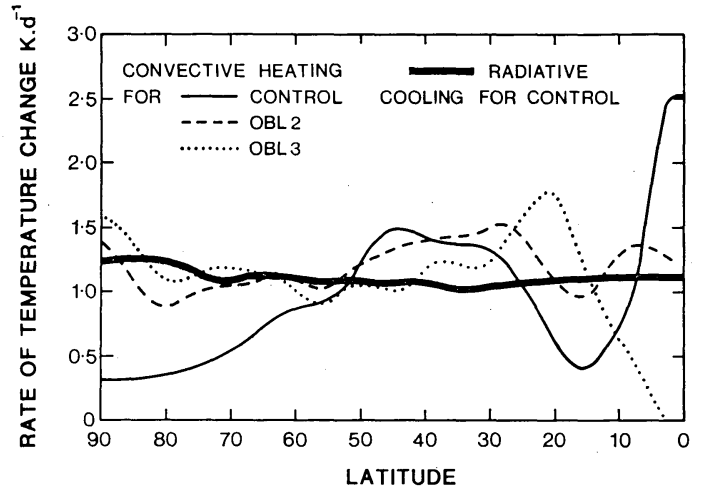

Fig. 10 Rate of change of temperature at level 17 $(2.4 \mathrm{~km})$ cwing to convection for the 3 experiments. The radiative cooling for the control only is shown for simplicity, this cooling for OBL2 and OBL3 was very similar to that of the control.

radiative cooling and the convective heating, as shown in Fig. 10 for a height of about $2.5 \mathrm{~km}$. In contrast the control run indicates that a substantial additional heating term (convergence of large scale eddy polewards flux of sensible heat) was needed at high latitudes. At low latitudes in the control the heating and cooling associated with the vertical motions of the mean meridional circulation dominated and largely counteracted the convective term. Similarly the opposite impact of the reversed cell for OBL3 can be distinguished.

Not unexpectedly in view of Figs. 3 and 4 OBL2 and OBL3 had much less kinetic energy and available potential energy than the control. Nevertheless, the baroclinic energy cycle between eddy available potential energy and eddy kinetic energy prevailed, and the usual energy transfers occurred except for a reversal in the direction of the zonal to eddy available potential energy transfers. An interesting perturbation occurred in the wave energy vertical flux of geopotential height, which for the control showed maximum interaction between troposphere and stratosphere occurring at high latitudes, see Hunt (1976). In OBL2 this flux maximised in the tropics in conjunction with the very weak winds prevailing there, while in OBL3 this flux was located in the subtropics, with its maximum value greatly reduced, presumably in agreement with the requirements of the Charney-Drazin theory for strong east winds.

The latitudinal distribution of the atmospheric water vapour followed closely that of the tropo- 
spheric temperature distribution. The highest hemispheric mean precipitable water vapour amount was in OBL2 and the minimum in OBL3, but the range varied only from $2.7 \times 10^{-3}$ to $2.2 \times 10^{-3} \mathrm{~kg} \mathrm{~kg}^{-1}$. Again an examination of the zonal mean relative humidity in the 3 experiments revealed surprising overall similarities, the major difference being in OBL3 where the reversed tropical cell had increased the subtropical and reduced the tropical relative humidity. This suggests that a cloud forecasting scheme based on relative humidity might have produced rather similar zonal mean cloud amounts in the 3 runs, except for the low latitudes of OBL3. Any reduction in cloud cover in the tropics of OBL3 would, of course, tend to counter the surface temperature reduction caused by the high albedoes.

The precipitation and evaporation characteristics also changed markedly at high obliquity, with consequent climatic implications. Whereas the control run had a monotonically decreasing equator-to-pole zonal mean evaporation distribution, that for OBL2 was relatively flat except for a local maximum at low latitudes. OBL3 had a similar distribution except for a minimum in the tropics. These variations essentially followed from the surface temperature profiles. It should also be remembered that an underlying swamp condition was assumed. The precipitation rate for OBL2 identified very closely with its evaporation distribution, and while the tropical maximum was less than half of the control, the high latitude precipitation was more than doubled. Again OBL3 was very similar to OBL2 except for a

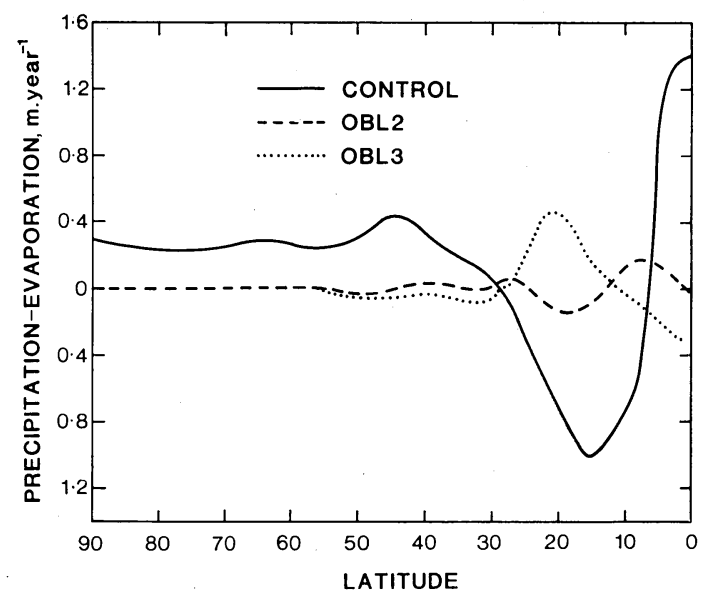

Fig. 11 Zonal mean difference of precipitation minus evaporation rates for the 3 experiments. tropical minimum. In fact the tropical precipitation for OBL3 was about 13 times smaller than for the control, a result directly related to the reverse mean meridional cell in this region.

The net imbalance between precipitation and evaporation is illustrated in Fig. 11 for the 3 runs. Clearly OBL2 was basically in local balance at all latitudes, as implied by Figs. 5 and 9 . The reversal of the mean meridional cell in the tropics between the control and OBL3 is reflected in Fig. 11, but polewards of $30^{\circ}$ latitude a local balance also occurred in OBL3.

\section{Concluding discussion}

For $0^{\circ}$ obliquity the current experiment suggests that, in general, the climate would be somewhat more vigorous, while at high latitudes it would be harsher, colder and have reduced precipitation. An overall contraction in the extent of the habitable zone could be expected. These conclusions, of course, are valid for current geography, cloud cover, etc., which might not necessarily apply for some past era when a smaller obliquity could have occurred, thus opening the possibility for additional climatic perturbations.

In the case of the $65^{\circ}$ obliquity the model results are more difficult to interpret because of the extreme seasonality which would occur in practice. Assuming that the model did adequately represent conditions appropriate to the annual mean, then it appears that low latitudes would be much drier and colder throughout the year, but not glaciated. OBL3 may represent summer conditions for $65^{\circ}$ obliquity as regards the latitudinal temperature gradient (rather than the actual temperatures) thereby implying that strong tropospheric easterlies would occur at low latitudes at this time. In fact a monotonic temperature gradient directed from the summer to the winter pole should exist, suggesting that the low latitude easterlies might extend over the equator, due to mean motions, to be replaced at higher winter latitudes by strong west winds. Obviously the polar regions would experience long, cold winters and long, hot summers. Because of the coldness of the winter atmosphere and its inability to hold water vapour snowfall would be reduced and it would melt entirely during the summer. On the other hand sea ice, for current geography, should readily form with its depth ultimately being limited by the conductivity of the ice itself. This might prevent the production of such thick sea ice that it could possibly sur- 
vive the intense summer insolation. If annual sea ice were to exist then the maximum summer temperatures would occur at middle latitudes producing a climate quite different to those of OBL2 and OBL3. Seasonal transitions for $65^{\circ}$ obliquity would be more marked than now, and clearly a much reduced habitable zone would be expected.

All else being equal it would seem that either higher or lower obliquities than the present $23.5^{\circ}$ would result in a less desirable climate on Earth. This raises the interesting question as to what is the "ideal" obliquity for a planet's climate, and what in fact determines the obliquity?

\section{References}

Hunt, B. G., 1976: Experiments with a stratospheric general circulation model. Part IV. Inclusion of the hydrologic cycle. Mon. Wea. Rev., 104, 333350 .

1979: The effects of past variations of the Earth's rotation rate on climate. Nature, 281, 188-191.

281, 310 .

Kukla, G., A. Berger, R. Lotti and J. Brown, 1981: Orbital signatures of interglacials. Nature, 290, 295-300.

Williams, G. E., 1975: Late Precambrian glacial climate and the Earth's obliquity. Geol. Mag., 112, 441-465.

- 1980: Matter arising-Effects of the Earth's rotation rate on climate. Nature, 286, 309.

Wolfe, J. A., 1978: A paleobotanical interpretation of Tertiary climates in the northern hemisphere. Amer. Sci., 66, 694-703.

\title{
黄道傾斜の変化が気候に及ぼす影響
}

\author{
B. G. Hunt \\ Australian Numerical Meteorology Research Centre
}

年平均状態を求める半球大循環モデルを用いて，黄道傾斜が， $23.5^{\circ}$ から $0^{\circ}, 65^{\circ}$ に变化することによって生 じた結果を考察した。この様な傾斜の值が, 過去の地質時代にとられていたといわれている。傾斜 $0^{\circ} の$ 気候 は, 現在の気候より変化に富み, 高緯度の地表面は, より寒冷で, 乾燥している。しかし, モデル対流圈は, 全 体的にやや温暖化している。傾斜 $65^{\circ}$ に対し実験を 2 例行なった。2 例とも高緯度で低アルベードだが，一方は 低緯度で氷河のアルベードを与㒵た。年平均状態に対し，最初の実験例では，対流圈の緯度方向の温度傾度が実 質上無かった。第 2 の実験例では赤道で地表温度が最低となったが，氷河状態になる程の低温に到らなかった。 この場合は「反転したハドレー細胞」によって, 熱帯東風ジェットが維持された。シミュレートされた水文学, エネルギー交換等を合わせて考虑すれば，ここで得られた結果はこの様に極端な傾斜における気候状態を考兵る 材料を与兄てくれる。地球の居住可能帯は, 傾斜 $0^{\circ}, 65^{\circ}$ 双方に対して, 減少すると結論される。以上の実験例 は, 色々提唱される仮説的気候状態を評価する上で, 大気大循環モデルは, かなりの未開拓な可能性を持ってい ることを示している。 